\title{
生活履歴曲線による回遊魚群の解析一 III
}

日本海と九州海域におけるマイワシ群の系統別年令と成長

\author{
安田秀明 \\ (1962 年 6 月 25 日受理)
}

\author{
GRANOGRAPHICAL LIFE RECORD CURVE METHOD FOR \\ IDENTIFYING EACH STOCK OF PELAGIC FISHES-III \\ APRAISAL OF THE AGE AND GROWTH BY STOCK FOR SARDINE \\ GROUPS IN THE JAPAN SEA AND WEST KYUSHU WATERS \\ Hideaki Y ASUDA $^{*}$
}

\begin{abstract}
In this part of his granographical studies, the author tries on the basis of the data published in References 1 and 2 (see the corresponding column below) to answer the unsettled problem as to whether sardine yearlings having formed summer rings can or cannot further form winter rings within the year. In Table 1 and Fig. 1 are illustrated the data as the distinctiveness between the summer ring and the winter ring. While the first peak on life record curve draun for Stock $\mathrm{D}$ or $\mathrm{E}$ relates to the summer ring, other peaks correspond all to winter rings (see Fig. 3). From the known conformity of the time of spawning to that of scale-ring formation, it follows that these winter rings represent the annual rings proper. It was thus confirmed the possibility of that yearling sardine of some stock forms both summer ring and winter one. As to the embodiment of said possibility, however, the growth is not alone the determining factor.

Referring to life record curve, it seems likely that each winter ring is produced as a configuration accompanied by e secondary ring to be formed contiguously to the former.

The relation discovered between the age and growth is illustrated in Table 2 and Fig. 2.
\end{abstract}

\section{年令查定の問題点}

安田・小倉 ${ }^{n}$ はマイワシ個体の鳞に現われるすべての輸紋について，輸絞長の極大頻度を調べた結果から 年令を查定した。その報文で 4 月頃に輸紋を形成するもの（常盤沖 2 年魚）と，同じ当年魚 (東京湾)でる 9 月頃に輸紋を形成するすのと，さらに1～2 月に至つても輪紋を形成しない群とがあることを知つた。 つぎに安田 ${ }^{21}$ は年令括よび成展に関するシンポジニームで取报かれたいくつかの文献によつて，当才魚に 特いては最初の輸紋は, 比較的成長のよいもの（発生の早いもの）で注 $7 \sim 10$ 月に, 成長の悪いるの（発生

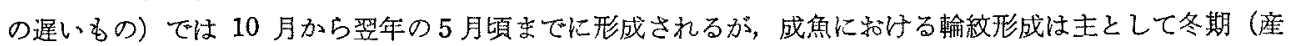
卵期) だけに行なかれるといらことを述いた。しかし，夏輪を形成した当年魚がその年に冬輪を形成するか

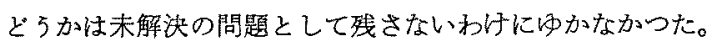

この報文は上述の問題点を吟味し，鳞によるマイワシの年令查定が因難であつた原因は，当才魚で年に 2 輪を形成するものと1輪を形成するものとの両者がともに存在していること，括よび 2 次的輸紋を形成する るのが比較的多く存在することにあることを確めた。

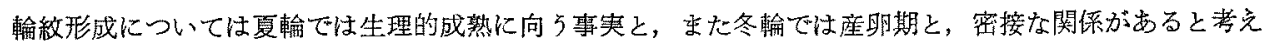

* 東京水産大学 (Tokyo Univ. Fish.). 
られる。

\section{試料と方 法}

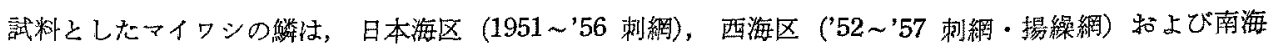
区（'59 刺網・羊網・小台網）の各水産研究所にプレパラートにして保管されていたるのの一部ずつを借 用した。

さき著者が述べた魚群の輸敘学的生活履暨曲線，すなわち，鱗に現われるすべての輸紋を多数の個体に ついて測定し，輪觓形成時の棓算体長 に直したものから体長何 $\mathrm{cm}$ のとき 何\%の個体が輪紋をもつたかを示す曲 線を描いた (3, $^{3,5)}$ 。乙れらの图から第 1 輪紋の鉒の位置の体長頻度の大きさを 調へると Table 1 の第 $2 \cdot 3$ 段の上うに なる。計算体長が $7 \sim 10 \mathrm{~cm}$ と $11 \sim$ $16 \mathrm{~cm}$ のつに別かてるすのとして， 最初の輪呅が $7 \sim 10 \mathrm{~cm}$ にある群につ いての第 2 輪紋の峷に対応する体長頻 度を第 4 段に示した。第 3 段の体長が

Table 1. Frequency represented as number of sardine groups of a calculat body-length corresponding to the time of ring formation

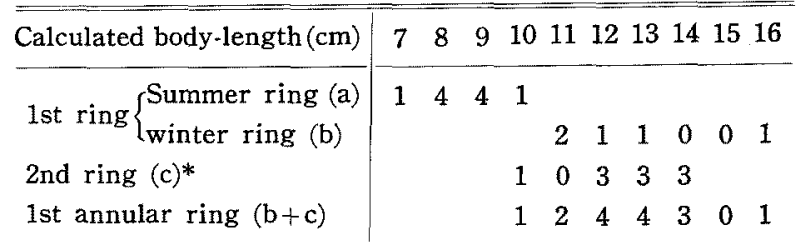

* The second ring of sardine individuals judjed to be smaller than $11 \mathrm{~cm}$ at the time of 1 st ring formation.

$11 \mathrm{~cm}$ 以上のるのと第 4 段のものとを合計して第 5 段に示す。Fig. 1 は生活履糜曲線の型別に整理 的に集計する以前に括㚈る郝の特のの群についての 資料によるものである。

Table 1 と Fig. 1 とから, 体長 $7 \sim 10 \mathrm{~cm}$ に輪 紋を子つ第 2 段の体長組成と，10 16 cm に輪絞を るつ第 5 段の体長組成之の両者はいずれも正規分布 曲線に似た形を示すとみなされる。

したがつて，体長 $10 \sim 11 \mathrm{~cm}$ のとこるで第 1 辆 紋の体長組成を 2 つ分かつことは妥当である。

当才魚に夏輪を形成するといら上述の事項ととも に, 当才魚の平均体長の時期的变化が 冬期に 11 $15 \mathrm{~cm}$ となるという事項るまた知られているので, Table 1 と Fig. 1 の体長 7 10 cm のところの山 は夏輪であり，第 5 段の $10 \sim 16 \mathrm{~cm}$ のところの山 は第 1 冬輪であることがわかる。

\section{結果と考察}



Fig. 1. A set of body-length distribution curves indicating the distinction between the body-lengths corresponding to the times of formation for summer ring and winter ring, respectively.

Abscissa: Calculated body-length (cm). Ordinate: Frequency of appearance of a particular body length $(\%)$.

上述の上 3 にして夏輪と第 1 冬輪とを区別し，それから後は年 1 輪ずつを冬期（産畉期）に形成したるの とみなすと，年令と成長との関倸は Table 2 の灰側のよ5になる。Table 2 の右側は生活履歴曲線のそれ ぞれの山に含まれる頻度数の和をそれそれの個体数で除して得られた輪紋出現率である。生活履歴曲楾の型


報告する予定である。

Table 2 の 1951 '57 年 (日本海と九州西海㟶) と'59 年 (南海区) の海区別魚群と 1943 '47 年に 10 カ所で採鱗したごく少数の試料とについて定差図を描くと Fig. 2 のよ ろになる。前者の力の極限值は 28 
Table 2. Body length at the time of scale ring formation calculated for various sardine stocks according to the observed number of rings on one scale. (The numerals in parenthesis represent the body-length actually observed for sardine individuals just at the time of scale formation.)

\begin{tabular}{|c|c|c|c|c|c|c|c|c|c|c|c|c|c|}
\hline \multirow[b]{2}{*}{ Type } & \multicolumn{6}{|c|}{ Body-length in $\mathrm{cm}$} & \multirow{2}{*}{$\begin{array}{l}\text { Number of } \\
\text { individuals }\end{array}$} & \multicolumn{6}{|c|}{ Total rings/Number of individuals } \\
\hline & 0.5 & 1 & 2 & 3 & 4 & 5 & & 0.5 & 1 & 2 & 3 & 4 & 5 \\
\hline $\begin{array}{l}\mathrm{A} \\
\mathrm{B} \\
\mathrm{C} \\
* \\
* *\end{array}$ & $\begin{array}{l}7.7 \\
8.4 \\
8.2 \\
9.7\end{array}$ & $\begin{array}{l}11.8 \\
14.4 \\
11.7 \\
12.3 \\
13.4\end{array}$ & $\begin{array}{l}15.1 \\
16.6 \\
14.6 \\
15.6 \\
16.6\end{array}$ & $\begin{array}{l}18.8 \\
19.5 \\
18.2 \\
18.8 \\
18.6\end{array}$ & $\begin{array}{c}(20.7) \\
(20.5) \\
20.8\end{array}$ & 22.4 & $\begin{array}{r}421 \\
34 \\
285 \\
316 \\
33\end{array}$ & $\begin{array}{r}1.2 \\
1.1 \\
1.0 \\
.9\end{array}$ & $\begin{array}{l}1.5 \\
1.1 \\
2.1 \\
1.7 \\
1.4\end{array}$ & $\begin{array}{l}1.8 \\
1.2 \\
1.6 \\
1.7 \\
1.3\end{array}$ & $\begin{array}{r}1.7 \\
1.2 \\
1.7 \\
1.7 \\
.9\end{array}$ & $\begin{array}{r}.3 \\
1.2\end{array}$ & 1.1 \\
\hline $\begin{array}{l}D \\
E \\
F \\
G \\
H \\
I\end{array}$ & $\begin{array}{l}7.6 \\
8.7\end{array}$ & $\begin{array}{l}12.5 \\
13.6 \\
10.8 \\
11.5 \\
12.8 \\
15.8\end{array}$ & $\begin{array}{l}15.7 \\
16.8 \\
14.6 \\
15.1 \\
15.4 \\
19.4\end{array}$ & $\begin{array}{r}18.8 \\
19.5 \\
17.8 \\
18.6 \\
17.5 \\
(20.7)\end{array}$ & $\begin{array}{c}(20.4) \\
19.5 \\
(20.5) \\
19.3\end{array}$ & & $\begin{array}{r}53 \\
629 \\
49 \\
338 \\
99 \\
49\end{array}$ & $\begin{array}{l}1.1 \\
1.4\end{array}$ & $\begin{array}{l}1.9 \\
2.2 \\
1.1 \\
1.4 \\
.95 \\
2.0\end{array}$ & $\begin{array}{l}1.6 \\
1.8 \\
1.1 \\
1.8 \\
1.3 \\
1.6\end{array}$ & $\begin{array}{l}2.3 \\
.83 \\
1.5 \\
2.0 \\
.91\end{array}$ & $\begin{array}{l}1.1 \\
.92\end{array}$ & \\
\hline
\end{tabular}

A, B and C: Stocks in the Japan Sea.

$\mathrm{D}, \mathrm{E}, \ldots, \mathrm{I}$ : Stocks in west-coastal waters of Kyushu.

* Mixed group consisting of $\mathrm{A}$ and $\mathrm{C}$.

** Mixture of sardine individuals caught in Akita, Niigata and Ishikawa, their body-length falling in a range of $22.5-23.4 \mathrm{~cm}$.



Fig. 2. A. WALFORD-graph applied to catches of Japanese sardine.

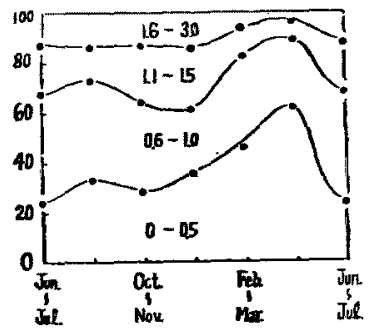

Fig. 3. Seasonal variation of relative appearance of such sardine individuals of 3 or 4 years old as particularized in the distance between outermost scale ring and scale periphery. Numerals in the figure stand for said distance represented as the number of units (one unit $=0.516 \mathrm{~mm}$ ). Sardine individuals were counted in summation by every two months. Jun. Jul., 243; Aug. Sept., 113; Oct. $\sim$ Nov., 118; Dec. Jan., 148; Feb. Mar., 100; Apr. May, 187.

$\mathrm{cm}$ て，後者の方は $24 \mathrm{~cm}$ である。

成魚の䑫について最外側の輪紋から鱗の緣までの間隔を5つの段階に分け，それらの各段階の出現率（\%) と採集月との関缧をFig. 3 に示す（この試料には上記の3 海域の他に東游区の分も含まれている）。

Fig. 3 から，あ立り明膫ではないが，成魚でもこく僅加の個体は夏輪と冬輪と在形成することが知られ

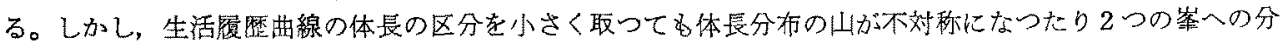


割を招いたりすることはみられなかつた。

試料を貸与された水産䃑觉所内橋・伊藤両所長，横田支所長，伊東就方・木部崎修両技官に感謝する。

$$
\text { 文献 }
$$

1）安田秀明・小會通男：日本産主要魚類の成長－Ｉ マイワシ，本誌，16 (6)，1950.

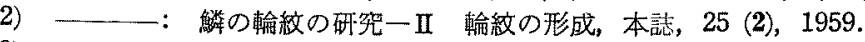

3）—・伊東䃄方：生活履歴曲線による回遊魚群の解析一I 日本海区に括けるマイワシの系統群， 本誌, 28 (6), 1962.

4) ————II 九州西海岸に怙けるマイワシの系統 群, 本誌, $29(\mathbf{1}), 1963$.

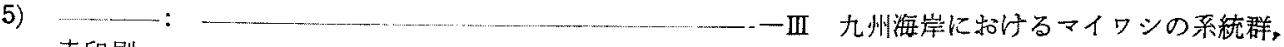
未印刷。 